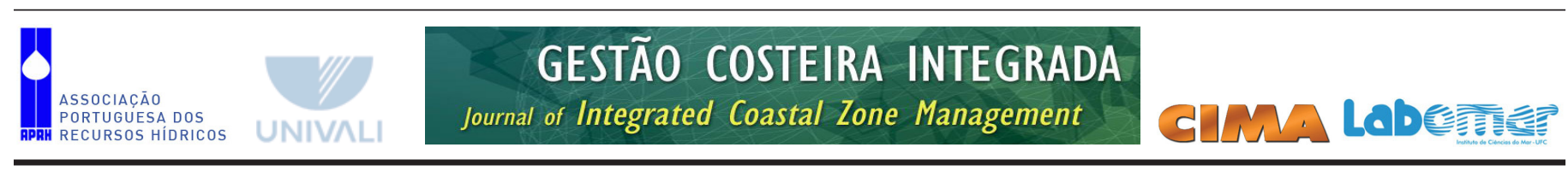

http://www.aprh.pt/rgci/pdf/rgci-418_Massmann.pdf | DOI:10.5894/rgci418

\title{
Qualitative social vulnerability assessments to natural hazards: examples from coastal Thailand *
}

\author{
Avaliação qualitativa da vulnerabilidade social a riscos naturais: \\ exemplos da zona costeira da Tailândia
}

\author{
Frederick Massmann ${ }^{1} \&$ Rainer Wehrhahn ${ }^{\circledR, 1}$
}

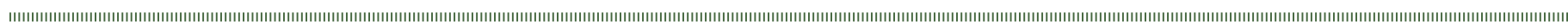

\begin{abstract}
Information on the vulnerability to natural hazards on a local level may help decision makers, stakeholders, and others to make better decisions regarding an effective disaster management. Qualitative research methods can reveal such information. This paper reports on the application of focus groups and individual interviews for the assessment of local vulnerabilities in two case studies. The first case study deals with the impact and aftermath of the tsunami 2004 in Southern Thailand and the second one with urban flooding in Bangkok. Empirical research for both examples has been conducted from 2009 to 2012. The results show that a combination of different forms of qualitative interviews can reveal significant information for sustainable risk management. The specific characteristics of qualitative methods, e.g. openness and flexibility, allow for creating a holistic picture of local vulnerabilities. Furthermore, deeper knowledge of individual agency as well as of structural conditions can be generated. It could be shown that income diversification and social networks play a crucial role in reducing vulnerability to tsunami hazards whereas the lack of preparation on all levels in return increases vulnerability. Flood prone communities in Bangkok benefit from strong local organizations that represent their interests and that are active in flood risk management as well as from institutionalized savings and loans. A serious constraint for vulnerability reduction is unclear land tenure since it impedes individual and community efforts.
\end{abstract}

\section{RESUMO}

As informaçóes sobre a vulnerabilidade a riscos naturais ao nivel local podem constituir apoio importante para os tomadores de decisáo e para as partes interessadas (stakeholders) no sentido em que viabilizam decisóes mais eficazes no que se refere à gestão de desastres. Os métodos de pesquisa qualitativos podem fornecer essas informaçóes. Este artigo aborda a vulnerabilidade local através de dois estudos de caso em que foram utilizadas entrevistas individuais e discussóes de grupo (focus groups) como forma de avaliar a aludida vulnerabilidade. O primeiro estudo de caso incide nos impactes e consequências do tsunami de 2004 no sul da Tailândia. O segundo refere-se às enchentes urbanas em Bangkok. Em ambos os casos utilizaram-se métodos empíricos cujos trabalhos decorreram entre 2009 e 2012. Os resultados obtidos indicam que a combinação de diferentes formas de entrevistas qualitativas pode revelar informaçóes importantes para a gestão de risco sustentável. As características específicas dos métodos qualitativos como, por exemplo, abertura e flexibilidade, permitem a construção de uma panorâmica holistica das vulnerabilidades locais. Além disso, podem gerar-se conhecimentos mais aprofundados nas instituiçóes consideradas individualmente, bem como nas próprias condiçóes estruturais. Pode demonstrar-se que a diversificação de renda e as redes sociais desempenham um papel crucial na redução da vulnerabilidade aos riscos do tsunami e que a falta de preparaçâo a todos os niveis, se traduz, pelo contrario, num aumento da vulnerabilidade. Por outro lado, as comunidades de Bangkok beneficiam de organizaçóes locais fortes que representam os seus interesses e que são activas na gestão dos riscos de cheias e inundaçôes, bem como da poupança institucionalizados e empréstimos. Um grave obstáculo para a redução da vulnerabilidade é o sistema menos claro da posse da terra, pois que tal impede que os esforços individuais e das comunidades sejam mais eficazes.

@ - Corresponding author: wehrhahn@geographie.uni-kiel.de

1 - Department of Geography, Christian-Albrechts-University Kiel, Germany

* Submission: 15 May 2013; Evaluation: 12 June 2013; Reception of revised manuscript: 6 July 2013; Accepted: 29 July 2013; Available on-line: 8 August 2013 


\section{INTRODUCTION}

In the scope of a continuous intensification of negative impacts from natural hazards on human societies, the assessment of vulnerability becomes increasingly important, especially since the scientific focus shifted from a technical hazard perspective to a more social centered one. The implementation of activities to reduce negative impacts or rather people's vulnerability is bound to an understanding of who is vulnerable and why. In 2005 the World Conference on Disaster Reduction called for improvements in measuring vulnerability to give decision makers a working basis as it plays a crucial role in disaster preparedness and risk management (Bogardi 2006). The main outcome of the conference was the Hyogo Framework for Action that aims at reducing future disaster losses. It stresses the importance of an integration of the local level to successfully achieve this aim (UNISDR 2007).

In the recent past Thailand was struck by two major natural hazards, the 2004 tsunami and the 2011 flood. Both events impacted coastal regions and river basins respectively and highlighted the vulnerability of local communities to external shocks. The 2004 Indian Ocean Tsunami hit the Andaman Coast of Thailand and resulted in 5395 casualties and seriously disturbed livelihoods through damage and destruction of houses, assets and natural resources. The most affected province was Phang-Nga where 4224 people lost their lives (Thanawood et al. 2006). Central Thailand is subject to periodical and severe flooding triggered by a combination of heavy precipitation and run-off, sea level rise, land subsidence and human activities in former wetland areas. In 2011 the worst flood event since several decades affected huge parts of central and northern Thailand and above all the capital city Bangkok. According to estimations of the World Bank 680 lives had been lost and the economic damages accounted for approximately USD 46.5 billion. The most affected households were farmers in rural areas and the urban poor (World Bank 2012).

Both events, the 2004 tsunami and the 2011 flood, showed that the quality of the impacts on households and individuals vary widely according to their general vulnerability levels. The recovery period as well as the implementation of adaptation strategies revealed discrepancies. Some households recovered much faster than others despite equal damages and they chose different measures to adapt to future hazards. These differences are determined by the vulnerability of the households which in turn is constituted by various interlinked factors. To identify and analyze those factors a vulnerability assessment on the local level has been carried out. As conceptual background, we used the holistic vulnerability framework for coupled human-environment systems developed by Turner et al. (2003). The first of our two case studies deals with vulnerabilities of households in two coastal communities in Phang-Nga struck by the 2004 tsunami. The second study analyzes vulnerabilities in two urban communities exposed to river flooding in combination with seaward tidal influences in the megacity of Bangkok.

Methodologically, we report on the use of qualitative methods, namely individual interviews and focus groups, to learn from local people about factors constituting their vulnerability, how they coped with the disaster and what adaptation efforts they undertook. We argue that assessing the vulnerabilities of affected communities - analytically broken down to the household and individual levels - is essential to approach certain determining factors and thus reduce negative impacts of future events and to build resilience. Here the characteristics of a qualitative assessment can help to reveal power relations, hidden constraints and other important elements shaping the vulnerability.

\section{VULNERABILITY AND ITS ASSESSMENT}

Vulnerability is a currently very much debated term and concept respectively, amongst others in the context of climate change and natural hazards, resulting in various definitions and approaches to its operationalisation (e.g. Adger 2006, Gallopin 2006, Bohle \& Glade 2007, Kuhlicke et al. 2011; for social vulnerability explicitly cf. Cutter et al. 2003). In this paper vulnerability is understood as the degree to which a community, a household or a person is "likely to experience harm due to exposure to a hazard, either an exogenous perturbation or an endogenous stress or stressor" (Turner et al. 2003). Using this adapted definition in combination with the associated vulnerability framework for coupled human-environment systems (Turner et al. 2003) gives consideration to the complexity of vulnerability and makes clear that it consists of multiple interacting social, economic and environmental factors operating on different spatial scales (Fig. 1). In many schools of thought it is agreed that the concept of vulnerability comprises three fundamental dimensions, namely exposure, susceptibility and resilience/ adaptive capacity (Adger 2006, Birkmann 2006, Gallopin 2006). The operationalisation of the framework is no easy task. However, we assume that it can serve as a valuable starting point to approach the complexity of the flood situation in Bangkok and the tsunami aftermath at the Andaman Coast. We followed the recommendations of Turner et al. (2003) and focused on certain elements of the framework that can be arranged under the dimension susceptibility and particularly resilience. The element resilience comprises the ability of a system to cope with or adapt to stresses without fundamental changes. According to Birkmann (2011) the term coping describes the direct reaction of a society or community to the impacts of a hazard whereas adaptation takes place after the disaster and refers to medium- and longterm strategies.

Vulnerability is not only scale- and time-specific and socially, economically and environmentally contextual but also historical embedded (Wisner et al. 2004). Thus, conceptual research on vulnerability and particularly the assessment is very challenging and interdisciplinary approaches are needed (Hufschmidt 2011, Kuhlicke et al. 2011, Kienberger et al. 2012). Spatial vulnerability assessments mostly rely on quantitative data such as statistics (Fekete 2011) but the local "situativeness of vulnerability" can only be understood by using qualitative methods (Wisner 2004). Another important aspect of vulnerability connected to questions of complexity is its governance relevance (Medd \& Marvin 2005). Pelling (2003) argues that a consideration of all relevant actors involved in disaster management is the 


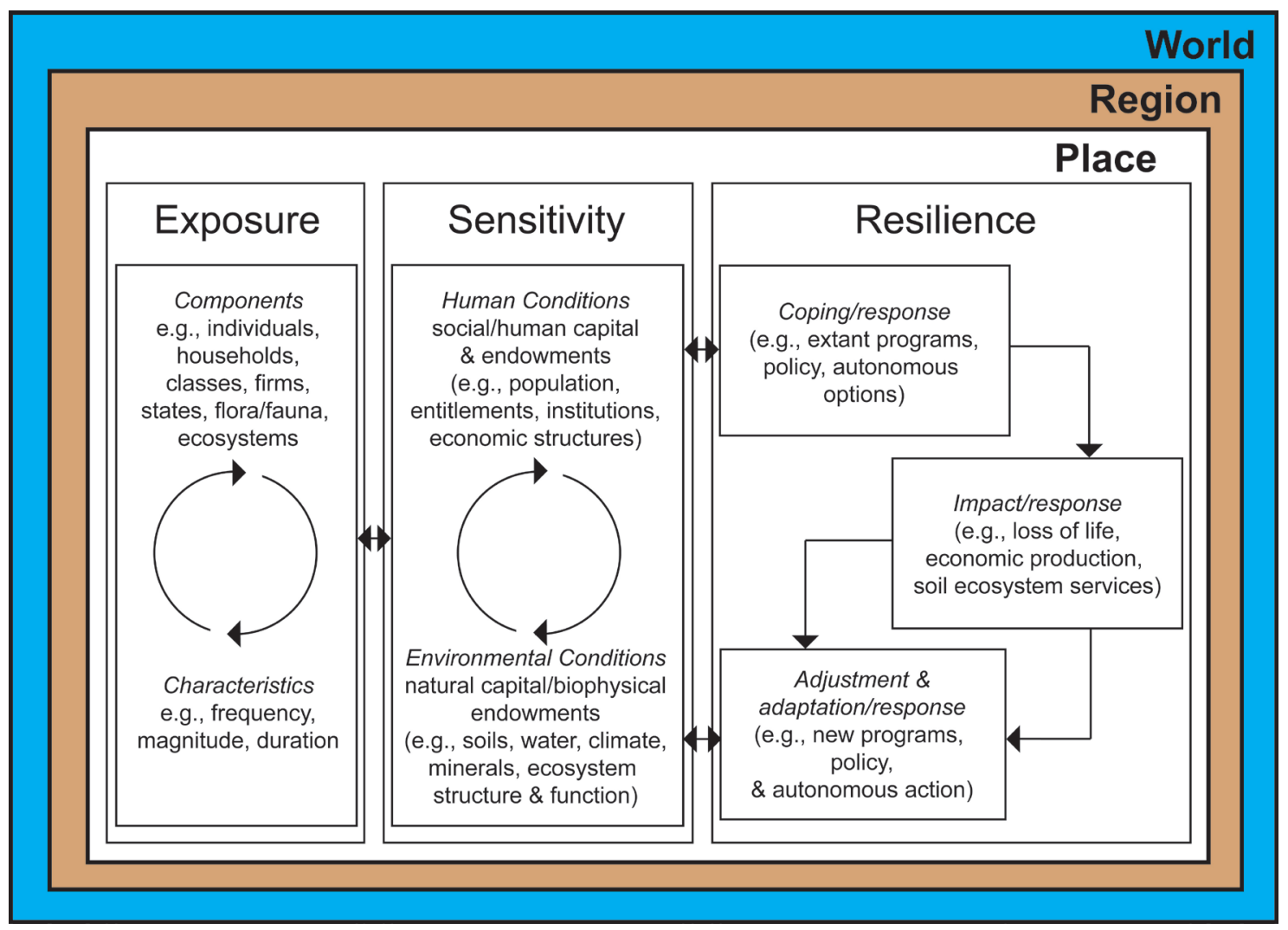

Figure 1. Conceptual vulnerability framework (based on Turner et al., 2003).

Figura 1. Contexto conceptual da vulnerabilidade (baseado em Turner et al., 2003).

key to make a first step towards reducing vulnerability to natural hazards. The adaptive capacity of a reference object is significantly determined by the institutional environment within which adaptation takes place, political influence and social networks (Smit \& Wandel 2006). Lebel et al. (2010) and Webster \& McElwee (2009) identified various actors and institutions that are of importance for Thailand's risk management and thus shaping local vulnerabilities.

There are many approaches to measuring vulnerability to natural hazards (Birkmann 2006, Fuchs et al. 2012). On a global to national scale quantitative assessments using indicators like the Disaster Risk Index (DRI) from the UNDP are very common (Cutter et al. 2003, Brooks et al. 2005). Approaches at the local level are quantitative as well as qualitative, depending on research questions and data availability. A study, which assesses the economic vulnerability of households to tsunami hazards was carried out by Willroth et al. (2011) who used a quantitative household survey in combination with a statistical model. Wisner (2006), in comparison, applied qualitative selfassessment tools to investigate the coping capacity of local people in drought-prone southern Zimbabwe. Bercht \& Wehrhahn (2010) and Wehrhahn et al. (2008) focused on different individual components of the vulnerability of threatened urban inhabitants in Guangzhou, China. Their field studies were based upon a set of qualitative methods like in-depth and semi-structured interviews and photointerpretation, which were partially linked with the results of quantitative approaches used for ecological vulnerability assessment. Willroth et al. (2012) applied qualitative as well as quantitative methods to identify and analyze adaptation strategies in the context of the tsunami 2004 by applying the vulnerability framework by Turner et al. (2003). Another study that successfully used this framework was conducted by Kaplan et al. (2009).

Generally speaking, qualitative approaches in human geography evolved above all when humanism flourished in the 1970s and 1980s as a result or rather criticism on positivist thinking. Humanistic geographers shifted the focus to the human subject and how it experiences and constructs its world (Buttimer 1976, Tuan 1976). They emphasized the role of the researcher as an influencing interpreter of interpretations and paved the way for people-centered methods like participant observations, in-depth interviewing, focus groups, reading and interpreting of texts and images, etc. which are nowadays used in many sub disciplines (Rodaway 2011). Qualitative methods do not want to be representative but to reconstruct how people experience and make sense of their lives (Longhurst 2010). Thus, they try to take up the specific perspectives of the interviewees. In comparison to quantitative approaches in vulnerability research that usually result in lists of weighted indicators, these individual perspectives provide supplemental and deepened information about distinct perceptions and the handling of factors determining vulnerability. 


\section{METHODS AND CASE STUDIES}

\subsection{Individual interviews and focus groups}

The identification and analysis of factors determining the vulnerability of households in the selected study areas is based on qualitative research methods - individual interviews with local people, expert interviews and focus groups. Interviews and focus groups in particular aim to probe an issue in depth, that is to discover why people act the way they do and to explore human relationships and what role the specific context plays (McDowell 2010). Within science dealing with vulnerability to natural hazards many underlying factors are very well known and discussed such as age, gender, income, occupation, education and many more (Cutter et al. 2003). An individual interview e.g. specified as narrative, in-depth, exploratory or loosely structured interview, is a conversation with the purpose of eliciting data from the interviewees for further systematical analysis by asking questions and listening to what they say. Usually, an interview guide with a prepared set of questions builds the basis of the discussion. If the talk gets side-tracked, it is not seen as a problem, but is encouraged because often relevant and sensitive topics arise (Silverman 2010). Focus groups also are guided conversations but taking place in a group setting. Normally a focus group consists of two to 12 interviewees plus the interviewer, who defines the area of interest and directs the talk accordingly (for other definitions see Secor 2009 or Longhurst 2010). An advantage of focus groups is the large number of people and their opinions which can be handled in comparatively little time. Focus group conversations decenter the researcher, leading to a more balanced research relationship. In contrast to individual interviews a focus group builds on the dynamic interaction between the group members and can therefore reveal different opinions. Conversely interviewees in individual interviews may reveal information what they would never do in a group setting. Correspondingly the combined application of both introduced methods in form of a triangulation can maximize the depth of information received and also validate the results of the single methods (Elwood 2009, Nightingale 2009).

In both case studies the individual interviews and focus groups were carried out by a skilled moderator using an interview guide. The thematic key aspects of the interview guides comprised the three dimensions of exposure, sensitivity and resilience with a focus on the latter two. Aspects of social networks were assigned to the dimension sensitivity whereas livelihood diversification or the improvement of houses (e.g. uplifting, fortification) rather belongs to resilience. The important factors were derived from the literature and within the open and iterative research process. The interview questions tried to cover these factors entirely and also to reveal interlinkages between them. An example is asking questions about the importance of family and friends during a flood event or about common activities in the community to collect information on social networks. All conversations were tape recorded and subsequently transcribed. All focus group participants and most of the interviewees of the individual interviews were local people living in the case study areas (At the Andaman Coast: e.g. small-scale fishermen or plantation workers; In Bangkok: wageworkers or local business operators). The remains were stakeholders like government officials and NGO representatives responsible for risk management. The focus groups were composed homogenous with respect to occupational affiliation or other attributes but diverse within the group in order to achieve holistic results. For recruiting interviewees the snowball principle (Valentine 2005) was used.

In our research, both methods generated a lot of data in form of texts, either interview transcripts or notes. This abundance of information confronts the researcher with the challenges of interpretation and representation. We used an iterative, grounded theory approach for coding (Strauss 1987, Strauss \& Corbin 1990). The reading and rereading of the interview texts in combination with previous conceptual and theoretical knowledge allows for identifying recurrent and important topics respectively. On the one hand, we coded the existing text material according to our theoretical considerations, which build on Turner et al. (2003). On the other hand, we identified various superordinate and subordinate codes by repeatedly reading the texts. In an assignment process we created a complex coding structure for subsequent interpretation. For instance, the code "social networks" can be assigned to the dimension sensitivity and comprises information on different actors, forms of support, problems within community, etc.

\subsection{Case studies}

The two vulnerability assessments were carried out in two different case study areas in coastal Thailand (see Fig. 2). The first case study deals with the aftermath of the Indian Ocean tsunami of 2004 in rural coastal communities in Phang-Nga province and is based on 7 focus groups and 32 individual interviews. The second case study concentrates on flood-vulnerability in Greater Bangkok and comprises 4 focus groups and 36 individual interviews. The fieldwork for the tsunami-study took place in the period from August to October 2009 whereas the flood-vulnerability assessment was conducted from September 2011 until February 2012.

Phang-Nga province was severely affected by the tsunami, not only in terms of casualties and damage to property but also in terms of destruction of ecosystems and natural resources. The dominant land use is agriculture and fisheries which contribute $55 \%$ to the gross provincial product (GPP). Tourism is growing but still in its initial phase with a contribution of $2 \%$ of GPP (NESDB 2009). The two investigated coastal communities were Ban Nam Khem and the neighboring Khao Lak, which are situated approximately $100 \mathrm{~km}$ north of the booming tourism destination Phuket. Ban Nam Khem is a fishing village with rural surroundings, shaped by agricultural areas and aquacultures. It has its own fishing harbor with up- and downstream industries and more than half of all businesses in the village can be assigned to the fisheries sector (Massmann 2010). Prior to the Tsunami Ban Nam Khem had around 4,500 inhabitants. The other community, Khao Lak, is a fast growing tourism destination that focuses on high-class tourism and ecotourism. The development since the 1990s caused the decrease of (still existing) traditional activities such as small-scale fisheries and agriculture and influenced local population as well as local ecosystems. 

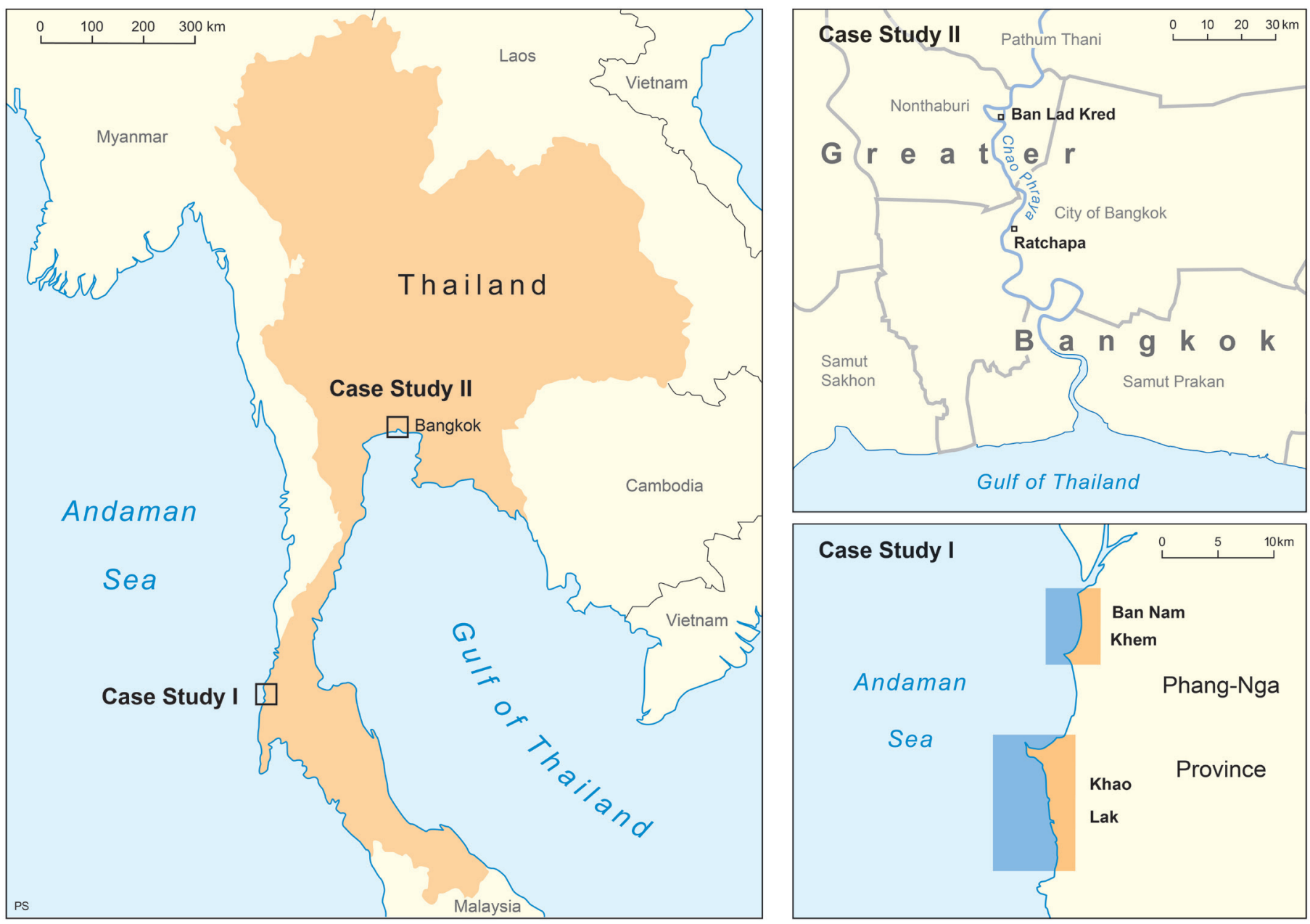

Figure 2. Location of case study áreas.

Figure 2. Localização dos estudos de caso.

Greater Bangkok, the second case study area, is prone to seasonal flooding caused by physical processes like heavy precipitation, land subsidence and sea level rise that are closely linked to human activities in low lying areas. Furthermore the region is characterized by social and economic inequalities and weak institutions on different spatial levels, which lead to various vulnerabilities ( $c f$. Roberts \& Kanaley 2006, World Bank 2009). The 2011 flood highlighted this particular situation and affected huge parts of the megacity, especially areas in the north and close to the Chao Phraya river. This study analyzes the vulnerabilities of households to flooding in Lad Kred Village on the stream island Kho Kred in the northern peri-urban part of Bangkok and in the innercity slum Ratchapa-Tubtim-Ruamjai (hereafter referred to as Ratchapa). Ban Lad Kred is home to 1062 inhabitants making their living mainly in tourism-related businesses, the manufacturing of handicrafts, and agriculture. The island Koh Kred is surrounded by the Chao Phraya river and is subject to regular recurring flood events with associated impacts (Local Administration Koh Kred, pers. comm., Bangkok, 2012). Ratchapa is a slum settlement located at the river banks of the Chao Phraya consisting of mainly stilt houses. The community is situated outside the flood walls and is not protected from changing water levels accordingly. The 825 inhabitants are affected from flooding especially when high water levels of the river meet with high seaward tides. Local people, to a large extend, are making their living with wage labor or fisheries (Local Administration Bangkok, pers. comm., Bangkok, 2012).

\section{ASSESSING SOCIAL VULNERABILITY IN COASTAL THAILAND}

Within their meta-analysis carried out to identify driving factors for social vulnerability to coastal hazards in Southeast Asia, Zou \& Wei (2010) found out that the most important determinants are population growth (including migration) in exposed areas, poorly planned urbanization, transformations of ecosystems and human conditions and basic rights (e.g. poverty, restricted access to resources, inequalities). With this paper we aim to contribute to this extensive collection in terms of highlighting the importance of local level factors. In the following we present results for each case study separately. We argue that the vulnerability of households in both projects is highly contextual and historical embedded. 


\subsection{Case Study I: Vulnerability of coastal communities to the Indian Ocean tsunami of 2004}

Based on qualitative interview data, an overview about factors constituting the tsunami vulnerability of households in Ban Nam Khem and Khao Lak was generated. The openness and the narrative character of individual interviews and focus groups allow for a comprehensive understanding of people's problems before, during, and after the tsunami event. In this manner the relevance of livelihood diversification and strong social networks for vulnerability reduction was emphasized. The diverse natural environment and the diverse income situation proved to be important determinants for a reduction of vulnerability. Ban Nam Khem and Khao Lak feature natural ecosystems like mangroves and coral reefs as well as human forms of land use like agriculture, fisheries, tourism, construction businesses, commerce and others. Despite the dominance of fisheries in Ban Nam Khem and tourism in Khao Lak we can refer to the areas as highly diversified (Fig. 3). Thus, a temporary or long-term loss of job due to the tsunami can be substituted quite easily (focus groups, pers. comm., Ban Nam Khem \& Khao Lak, 2009). According to the "philosophy of Sufficiency Economy" promoted by Thailand's King Bhumibol Adulyadej the people should strive for a moderate, self-dependent life without greed and overexploitation of natural resources (cf. Chalapati 2008). Many interviewees mentioned the King's philosophy and stated that they diversified their income already before the tsunami in terms of working in a second job in another sector and, more often, in terms of doing subsistence activities such as backyard farming (focus groups, pers. comm., Ban Nam Khem, 2009). In vulnerability research diversification is seen as a key factor in reducing vulnerability and building resilience (Bohle 2001, Turner et al. 2003, Wisner et al. 2004). De Silva \& Yamao (2007) showed for Sri Lanka that dependence on a single economic sector increases vulnerability to a tsunami and that diversified communities suffered less.
Social networks proved to have a strong influence on recovery in terms of support with money or goods from friends, family and neighbors. In case of mental problems due to loss of loved ones or injuries, existing networks also helped to cope by means of conversations and consolation. Interestingly the members of the social network, who were affected by the tsunami themselves, did not give any material support but mental backup instead. Very often social networks were used as a means to organize income substituting activities (focus groups, pers. comm., Ban Nam Khem \& Khao Lak, 2009). There is consensus that social networks are important determinants of vulnerability (e.g. Wisner et al. 2004, Thomalla et al. 2006). In some cases the tsunami negatively impacted social networks by destroying entire villages or neighborhoods. During the rebuilding phase families often were accommodated in different shelters and after rebuilding, the new houses many times didn't comply with the former household size (Fig. 3). Hence, families and also former neighborhoods were separated which severely disturbed social cohesion (ind. interviews, pers. comm., Ban Nam Khem \& Khao Lak, 2009). Particularly in the analysis of social networks, focus groups proved to be very useful as the interaction between the participants, the mentioning of names, and the way of talking about certain persons gives insight into the importance or unimportance of different parts of the network.

According to Berkes (2007) the Thai society had no social memory regarding tsunamis before 2004 except from some marginalized groups of indigenous fishing people. Accordingly most of the coastal dwellers didn't prepare themselves for a potential tsunami hazard at all. This was tragic because preparation is seen as a key factor in reducing negative impacts (Adger et al. 2005). In the aftermath of the tsunami preparation became a major concern on many levels. On the individual level people prepared folders with important documents, first aid kits, food and water, or flashlights to have it ready in case of an emergency. Furthermore people

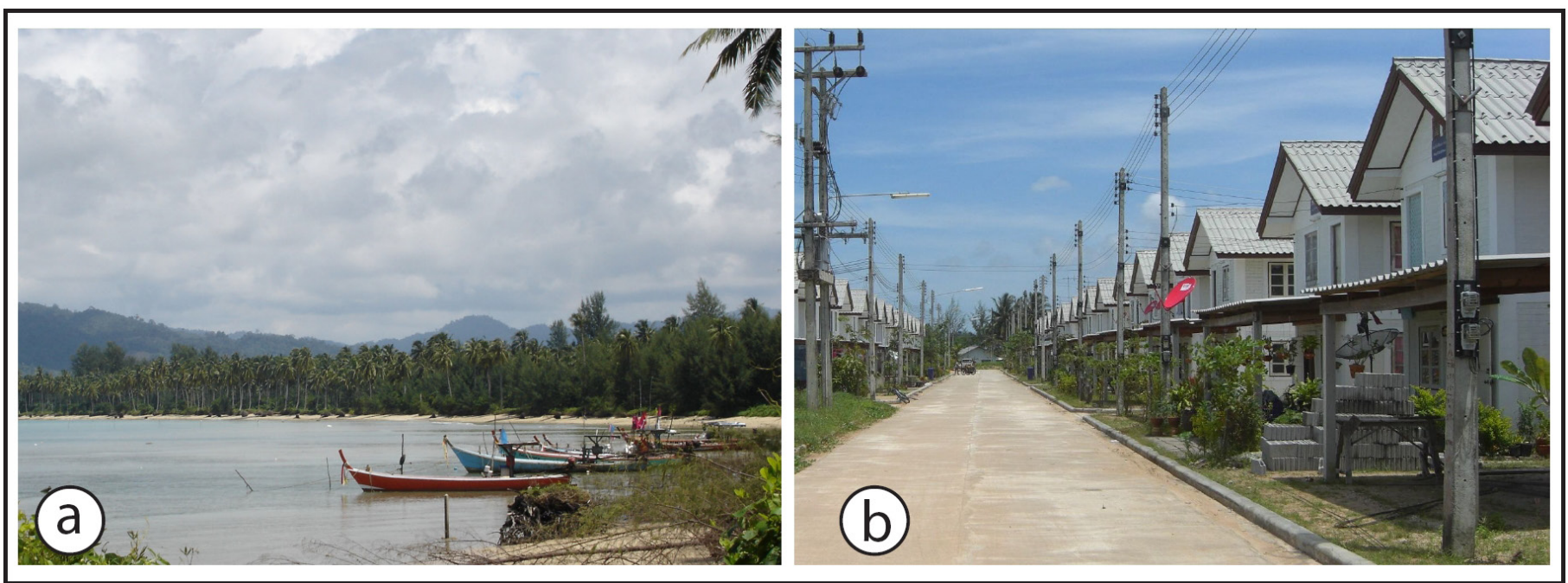

Figure 3. a) Small fishing boats and coconut plantation in Khao Lak. b) Newly built neighborhood in Ban Nam Khem after the tsunami. Figura 3. a) Pequenos barcos de pesca e plantação de coco em Khao Lak. b) Nova comunidade em Ban Nam Khem, construída depois do tsunami. 
engaged themselves in informing about escape routes and the location of the nearest tsunami shelter. Listening to the radio and watching the latest news in television became part of everyday life activities during the first years after the event. A major constraint in individual preparation is the fact that people's awareness ceases with the years (focus groups, ind. interviews, pers. comm., Ban Nam Khem \& Khao Lak, 2009). This corroborates with findings from Berkes (2007) who states that the social memory of hazards with a 60 -year frequency is not common or reliable.

The assessment of tsunami-vulnerability at the local level reveals that focus groups lead to different results than individual interviews. The topic of reconstruction in general and the planning of new houses in particular for instance was discussed very carefully within the focus groups because some participants were active stakeholders during the rebuildingprocess and thus are, at least to some extent, responsible for inadequate housing (focus groups, pers. comm., Khao Lak, 2009). In individual interviews people who were unsatisfied with the newly built houses unambiguously stated that they blame those people for the problem of separating families and weakening neighborhood-structures (ind. interviews, pers. comm., Ban Nam Khem, 2009). Another example is the increasing land consumption of tourism in Khao Lak and the displacement of traditional activities accordingly. In focus groups composed of farmers or fishermen the group dynamic often led to an intensive discussion in which many important aspects, above all negative aspects, of the tourism development emerged which could be responded to in individual interviews later (focus groups, pers. comm., Ban Nam Khem \& Khao Lak, 2009).

\subsection{Case Study II: Vulnerability of flood-prone communities in Bangkok}

To face recurrent flood events the inhabitants of Ban Lad Kred and Ratchapa developed various coping and adaptation measures like uplifting houses, building temporary walkways, or saving money (focus groups, ind. interviews, pers. comm., Ratchapa \& Ban Lad Kred, 2012). Coping and adaptation on a local level are integrated into multi-level institutional structures and governance processes (Lebel et al. 2010). Birkmann et al. (2010) call for a holistic acknowledgement of urban adaptation strategies and claim a new adaptive urban governance. We argue that governance on a local level has huge potential to influence vulnerability. Because of Thailand's administrative system (Wongpreedee \& Mahakanjana 2011) the responsible government bodies differ in both case studies. In Ratchapa an officially elected community organization that works on a voluntary basis represents the inhabitants whereas Ban Lad Kred has its village committee financed by tax revenues. However, a local representation of interests is able to manage community affairs and thus to reduce vulnerability. Both actors, the community organization and the village committee, are actively engaged in strengthening community cohesion by celebrating common holidays and by organizing regular meetings on which community-issues are dealt with (focus groups, ind. interviews, pers. comm., Ratchapa \& Ban Lad Kred, 2012). Before the theoretical background this support of social networks can be recognized as having a positive influence on the reduction of vulnerability. Another very important task of community organization and village committee is to implement coping and adaptation strategies on a community level like organizing mobile toilets during the flood, informing the locals how to behave, or installing an early warning system (Fig. 4). Therefore negotiation and cooperation with other actors is necessary (focus groups, ind. interviews, pers. comm., Ratchapa \& Ban Lad Kred, 2012). In vulnerability research local governance forms are seen as important determinants for building resilience (Pelling 2003).

The majority of houses in Ratchapa are built on the land of the Marine Department without permission. This

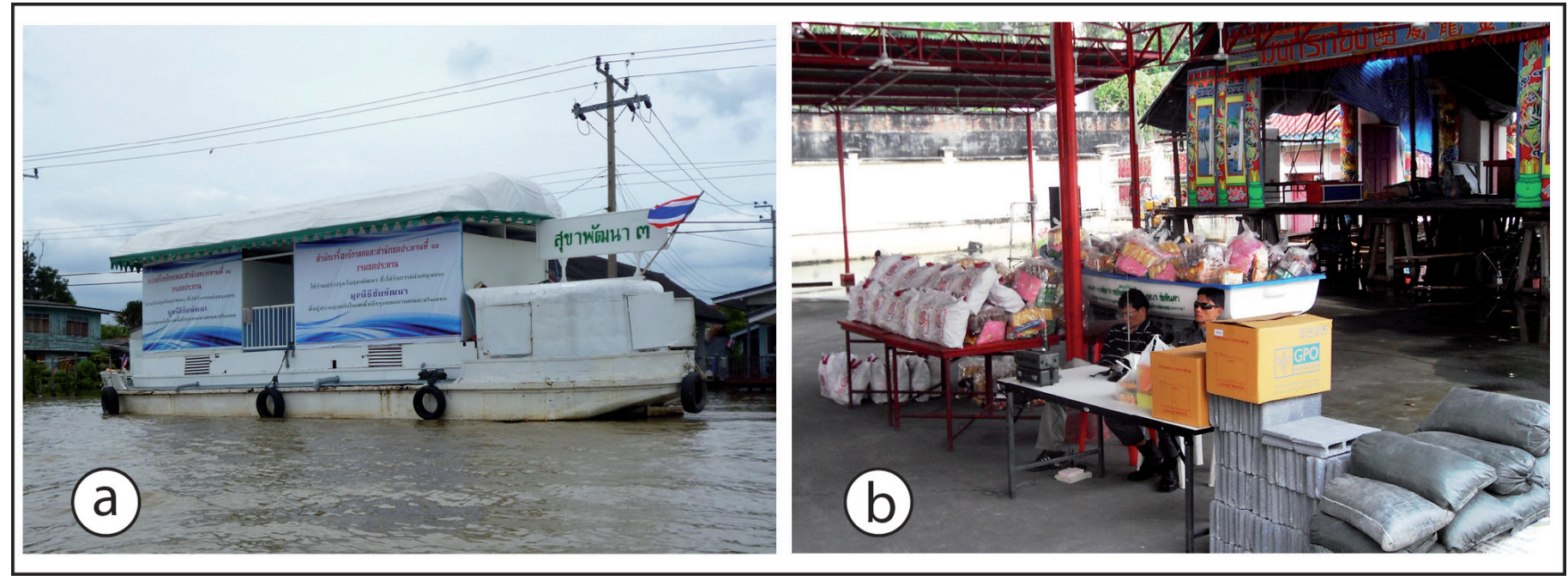

Figure 4. a) Mobile toilet in Ban Lad Kred organized by the village committee. b) Distribution of relief items by the military and the community organization in Ratchapa.

Figura 4. a) Banheiro móvel em Ban Lad Kred, estabelecido pela associação do bairro. b) Distribuição de bens de ajuda por militares e pela associaçâo de vizinhos do bairro de Ratchapa 
unclear land tenure highly impedes a successful adaptation on various levels. The households are not about to invest in the uplifting of their buildings to withstand higher water levels because they are afraid to be chased away in the long run (focus groups, ind. interviews, pers. comm., Ratchapa, 2012). Also the work of the community organization is influenced by this situation. The negotiation for external help proves to be very difficult because governmental and non-governmental organizations are not allowed to carry out structural projects like uplifting or improving walkways or other infrastructure in the community (ind. interviews, pers. comm., Ratchapa, 2012). Unsecure land tenure not only is a practical constraint for the local people but also affects them psychologically. Many interviewees stated that they are constantly afraid to be pushed away (focus groups, pers. comm., Ratchapa, 2012). It is consensus that land tenure is an important variable on vulnerability (Reale \& Handmer 2011).

The relevance of institutionalized savings and loans for community development and poverty reduction in Thailand was discussed intensivelyin variousstudies (e.g. Boonyabancha 2001, Boonperm et al. 2012). The mechanisms range from national programs like the "Village Fund" to local level savings groups without external support. We examined the influence of savings groups on the vulnerability of households to flooding and argue that it is a very effective tool for low income households as it compensates the lack of private savings. In both case studies self-organized savings groups exist. In Ban Lad Kred on the stream island savings groups have a general purpose and are used for everyday life expenses mostly. People also use the savings after a flood to replace damaged assets but they stress that they do not depend on it (focus groups, ind. interviews, pers. comm., Ban Lad Kred, 2012). In contrast the inhabitants of the slum settlement Ratchapa established a savings group only for flood-related damages. People use the money to purchase wood in order to repair damaged furniture, to replace destroyed electronical devices like refrigerators but also for long term investments like uplifting their houses (focus groups, pers. comm., Ratchapa, 2012). In low income settlements savings groups seem to have more potential to actually reduce vulnerability (cf. Cutter et al. 2003). In communities like Ban Lad Kred people generally have enough private savings to cope and adapt by themselves.

An issue that very often influenced the results of focus groups was the dominance of one or more participants. When the discussion centered on sensitive topics like land tenure, resettlement, or uneven distribution of external help, very often one or two eloquent respondents with a high socioeconomic status and thus power, dominated the talk and intimidated the others. To sustain a balanced exchange of arguments, the interviewer had to intervene and encourage the quiet participants to contribute.

\section{DISCUSSION AND CONCLUSIONS}

This paper presented selected results from two case studies in coastal Thailand where qualitative vulnerability assessments were conducted. Based on the holistic vulnerability framework for complex human-environment systems developed by
Turner et al. (2003) and theoretical considerations regarding the relation between vulnerability and complexity various vulnerability-determining factors could be identified. We agree with Birkmann et al. (2011) that a shift away from only structural measures as flood-protection towards a more integrative approach, incorporating governance, preparation, and planning is crucial to building resilience.

The key results of our study show that the vulnerabilities of households in Ban Nam Khem and Khao Lak to tsunami hazards are significantly influenced by the strength of social networks, diversified livelihoods, and individual preparation. Households in Bangkok that face regular floods rely very much on strong local organizations representing their interests and on access to financial capital to repair and rebuild their houses and assets again and again. A strong constraint for a reduction of vulnerability is unclear land tenure. The results were generated with a set of qualitative methods, namely individual interviews, expert interviews, and focus group discussions. Due to the qualitative characteristics of the methods, elements that do not fit into the well-known set of vulnerability-determining factors but nevertheless play an important role in shaping the susceptibility and adaptive capacity of households, can be identified and analyzed accordingly. Thus, a comprehensive picture that includes the perspectives of the persons concerned can be achieved.

The combination of individual interviews in conjunction with focus groups proved to be very useful in terms of revelation of differing results. The execution was comparably practicable because both methods relied more or less on the same discussion guide, were tape recorded and analyzed the same way. Also the recruitment process was similar and was conducted simultaneously. The primary difference was the dynamic within the two methods which resulted in sometimes differing results and thus contributed to a more comprehensive conclusion. Whereas in-depth interviews are a good opportunity for individuals to share information that they would not do in a group setting, focus groups can highlight a topic from different perspectives due to the group dynamic and therefore more comprehensibly. This corroborates with a study from Kaplowitz (2001), who carried out research in which he used individual interviews together with focus groups to assess mangrove products and services on a local level. In addition, the comprehension of quantitative methods could be reasonable in these cases because a mixed-method approach could, for example, provide more information about socio-economic household structures (Miller et al. 2010). Nevertheless Kabisch et al. (2011) state that only qualitative approaches give consideration to the complexity of vulnerability.

Complexity is a key characteristic of vulnerability which expresses itself in the various vulnerability determining factors and interrelations between those factors (Turner et al. 2003, Fig. 1). Social networks not only had a direct influence on the vulnerability of households in Ban Nam Khem and Khao Lak by providing emergency relief and financial capital for the rebuilding phase. They also played an important role for diversified livelihoods since it were often friends and neighbors who provided job opportunities. In Bangkok a strong social cohesion builds the basis for the existence or rather strength of community organizations 
and village committees to deal with flood problems. The other way round local governance has the potential to foster social networks by organizing common celebrations and other meetings. Another dimension of the complexity of vulnerability is its contextuality. To understand local governance processes, the power relations between locallevel actors (e.g. leadership, exclusion, etc.), and conflicts within the governance system, it is important to consider the context (Pelling 2003, Wisner et al. 2004). We argue that tracing back the historical development in the communities can reveal a lot of valuable information. The northern part of the slum-community Ratchapa used to be a Chinese trading post whereas the southern part was inhabited by Vietnamese Catholics. Despite the fact that nowadays it is one community, there is still a hidden boundary representing the historical differences that separate people and influence social cohesion and effective governance-processes. Besides identifying and analyzing vulnerability-determining factors, it is of great importance to pay attention to the complexity in order to really understand the vulnerable situation of the households.

Already in 2006 Janssen \& Ostrom (2006) called for a close link between governance and vulnerability and resilience by focusing on the governance-mechanisms that exert influence. In Ban Lad Kred and Ratchapa local governance was pointed out as an important factor for reducing vulnerability. A representation of local interests and a cooperation of local level actors can lead to improvements in community development and thus also tackle flood related problems. While there are a lot of constraints impeding the work of the community organization in the slum-settlement Ratchapa like financial limits, unclear land tenure, and hidden conflicts within the community, the village committee of Ban Lat Kred is facing less problems and can tackle flood related issues more effectively. Despite the many constraints in Ratchapa local-level organization plays an important role to better the flood situation.

An understanding of factors constituting social vulnerability is crucial to build future resilience as well as to develop successful adaptation strategies, which subsequently can be implemented on different levels. Based on the results of this paper a strong participation and integration of locallevel actors is needed in negotiating recovery and development strategies and plans. Recommendations for supporting social networks on a community level should be compiled and implemented by those actors. It also became clear that focusing on the most vulnerable households and groups, i.e. the urban poor, is necessary to reduce social vulnerability. The assessment of vulnerability is a complex task for which the application of qualitative methods, namely individual interviews and focus groups, proved to be very useful.

\section{ACKNOWLEDGEMENTS}

The research presented in this paper was carried out, in part, within the project "Tsunami Risks, Vulnerability and Resilience in the Phang-Nga and Phuket Provinces, Thailand" which was funded by the German Research Council (DFG). The data was collected in collaboration with Dr. Narumon Arunotai from Social Research Institute, Chulalongkorn University Bangkok.

\section{REFERENCES}

Adger, W.N.; Hughes, T.P.; Folke, C.; Carpenter, S.R.; Rockström, J. (2005) - Social-Ecological Resilience to Coastal Disasters. Science, 309(5737):1036-1039. DOI: $10.1126 /$ science. 1112122.

Adger,W.N.(2006)-Vulnerability. GlobalEnvironmentalChange, 16(3):268-281. DOI: 10.1016/j.gloenvcha.2006.02.006.

Bercht, A.L.; Wehrhahn, R. (2010) - A psychologicalgeographical approach to vulnerability: The example of a Chinese urban development project in the perspective of the transactional stress model. Environment and Planning $A$, 42(7):1705-1722. DOI: 10.1068/a42510.

Berkes, F. (2007) - Understanding uncertainty and reducing vulnerability: lessons from resilience thinking. Natural Hazards, 41(2):283-295. DOI: 10.1007/s11069-0069036-7.

Birkmann, J. (2006) - Measuring vulnerability to promote disaster-resilient societies: Conceptual frameworks and definitions. In: Birkmann, J. (eds.), Measuring vulnerability to natural hazards. Towards disaster resilient societies, pp.9-54, United Nations University, Tokyo, Japan. ISBN: 978-9280811353.

Birkmann, J. (2011) - First- and second-order adaptation to natural hazards and extreme events in the context of climate change. Natural Hazards, 58(2):811-840. DOI: 10.1007/s11069-011-9806-8.

Birkmann, J.; Garschagen, M.; Kraas, F., Quang, N. (2010) - Adaptive urban governance: new challenges for the second generation of urban adaptation strategies to climate change. Sustainability Science, 5(2):185-206. DOI: 10.1007/s11625-010-0111-3.

Bogardi, J. (2006) - Introduction. In: Birkmann, J. (eds.), Measuring vulnerability to natural hazards. Towards disaster resilient societies, pp.1-6, United Nations University, Tokyo, Japan. ISBN: 978-9280811353.

Bohle, H.-G. (2001) - Vulnerability and criticality: perspective from social geography. IHDP Update, Newsletter of the International Human Dimensions Programme on Global Environmental Change, pp.1-7.

Bohle, H.-G.; Glade, T. (2007) - Vulnerabilitätskonzepte in Sozial- und Naturwissenschaften. In: C. Felgentreff \& T. Glade (eds.), Naturrisiken und Sozialkatastrophen, pp.99119, Elsevier/Spektrum, Heidelberg, Germany. ISBN: 978-3827415714.

Boonperm, J.; Haughton, J.; Khandker, S. R.; Rukumnuaykit, P. (2012) - Appraising the Thailand Village Fund. World Bank Policy Research Working Paper 5998, 51p. DOI: 10.1596/1813-9450-5998

Boonyabancha, S. (2001) - Savings and loans; drawing lessons from some experiences in Asia. Environment \& Urbanization, 13(2):9-21. Available at http://www.bvsde. paho.org/bvsacd/cd26/enurb/v13n2/9.pdf

Brooks, N.; Adger, W.N.; Kelly, P.M. (2005) - The determinants of vulnerability and adaptive capacity at the national level and the implications for adaptation. Global Environmental Change, 15(2):151-163. DOI: 10.1016/j. gloenvcha.2004.12.006.

Buttimer, A. (1976) - Grasping the dynamism of lifeworld. Annals of the Association of American Geographers (ISSN: 0004-5608), 66(2):277-292, Washington, DC, U.S.A. 
Chalapati, S. (2008) - Sufficiency Economy as a Response to the Problem of Poverty in Thailand. Asian Social Science (ISSN: 1911-2017), 4(7):3-6, Toronto, ON, Canada.

Cutter, S.L.; Boruff, B.J.; Shirley, W.L. (2003) - Social Vulnerability to Environmental Hazards. Social Science Quarterly, 84(2):242-261. DOI: 10.1111/15406237.8402002

De Silva, D. A. M.; Yamao, M. (2007) - Effects of the tsunami on fisheries and coastal livelihood: a case study of tsunami-ravaged southern Sri Lanka. Disasters, 31(4):386404. DOI: 10.1111/j.1467-7717.2007.01015.x.

Elwood, S. (2009) - Mixed Methods: Thinking, Doing, and Asking in Multiple Ways. In: D. DeLyser (eds.), The SAGE Handbook of qualitative geography, pp.94-113, SAGE, London, U.K.. ISBN: 978-1412919913.

Fekete, A. (2011) - Spatial disaster vulnerability and risk assessments: challenges in their quality and acceotance. Natural Hazards, 61(3):1161-1178. DOI: 10.1007/ s11069-011-9973-7.

Fuchs, S.; Birkmann, J.; Glade, T. (2012) - Vulnerability assessment in natural hazard and risk analysis: current approaches and future challenges. Natural Hazards, 64(3):1969-1975. DOI: 10.1007/s11069-012-0352-9.

Gallopin, G. (2006)-Linkages betweenvulnerability, resilience, and adaptive capacity. Global Environmental Change, 16(3):293-303. DOI: 10.1016/j.gloenvcha.2006.02.004.

Hufschmidt, G. (2011) - A comparative analysis of several vulnerability concepts. Natural Hazards, 58(2):621-643. DOI: $10.1007 / \mathrm{s} 11069-011-9823-7$.

Janssen, M. A.; Ostrom, E. (2006) - Resilience, vulnerability, and adaptation: A cross-cutting theme of the international human dimensions programme on global environmental change. Global Environmental Change, 16(3):237-239. DOI: 10.1016/j.gloenvcha.2006.04.003.

Kabisch, S.; Kunath, A.; Schweizer-Ries, P.; Steinführer, A. (2011) - Vulnerability, Risks, and Complexity. Impacts of Global Change on Human Habitats. Hogreve, Göttingen, Germany. ISBN: 978-0889374355.

Kaplowitz, M. D. (2001) - Assessing mangrove products and services at the local level: the use of focus groups and individual interviews. Landscape and Urban Planning, 56(1-2):53-60. DOI: 10.1016/S0169-2046(01)00170-0

Kaplan, M.; Renaud, F.G.; Lüchters, G. (2009) - Vulnerability assessment and protective effects of coastal vegetation during the 2004 Tsunami in Sri Lanka. Natural hazards and Earth System Sciences, 9:1479-1494. DOI: 10.5194/ nhess-9-1479-2009.

Kienberger, S.; Blaschke, T.; Zaidi. R.Z. (2012) - A framework for spatio-temporal scales and concepts from different disciplines: the 'vulnerability cube'. Natural Hazards, DOI: 10.1007/s11069-012-0513-x.

Kuhlicke, C.; Scolobig, A.; Tapsell, S.; Steinführer, A.; De Marchi, B. (2011) - Contextualizing social vulnerability: findings from case studies across Europe. Natural Hazards, December 2012. DOI: 10.1007/s11069-011-9751-6.

Lebel, L.; Manuta, J. B.; Garden, P. (2010) - Institutional traps and vulnerability to changes in climate and flood regimes in Thailand. Regional Environmental Change, 11(1):45-58. DOI: $10.1007 / \mathrm{s} 10113-010-0118-4$.

Longhurst, R. (2010) - Semi-structured Interviews and
Focus Groups. In: Clifford, N. J.; French, S.; Valentine, G. (eds.), Key methods in geography, pp.104-115, SAGE, London, Great Britain. ISBN: 978-1412935081.

Massmann, F. (2010) - Analyse der Vulnerabilität von Landwirtschaft und Fischerei an der Andamanküste Thailands im Kontext des Tsunami von 2004. ChristianAlbrechts Universität zu Kiel. Unpublished thesis.

McDowell, L. (2010) - Interviewing: Fear and Liking in the Field. In: DeLyser, D. (eds.), The SAGE Handbook of qualitative geography, pp.156-171, SAGE, London, Great Britain. ISBN: 978-1412919913.

Medd, W.; Marvin, S. (2005) - From the Politics of Urgency to the Governance of Preparedness: A Research Agenda on Urban Vulnerability. Journal of Contingencies and Crisis Management, 13(2):44-49. DOI: 10.1111/j.14685973.2005.00455.x

NESDB (2009) - Gross regional and provincial products. p1, NESDB - National Economic and Social Development Board), Bangkok, Thailand.

Nightingale, A. (2009) - Triangulation. In: Kitchin, R. \& Thrift, N. (eds.), International encyclopedia of human geography, pp.489-492, Elsevier, Amsterdam, Holland. ISBN: 978-0080449111.

Pelling, M. (2003) - The Vulnerability of Cities: Natural Disasters and Social Resilience. Earthscan, London, Great Britain. ISBN: 978-1853838309.

Reale, A.; Handmer, J. (2011) - Land tenure, disasters, and vulnerability. Disasters, 35(1):160-182. DOI: 10.1111/ j.1467-7717.2010.01198.x.

Roberts, B.; Kanaley, T. (eds.) (2006) - Urbanization and Sustainability: Case Studies of Good Practice. Asian Development Bank. Mandaluyong City, Philippines.

Rodaway, P. (2011) - Humanism and People-Centred Methods. In: Aitken, S. \& Valentine, G. (eds.), Approaches to Human Geography, pp.263-272, SAGE, London, Great Britain. ISBN: 978-0761942627.

Secor, A. J. (2009) - Focus Groups. In: Kitchin, R. \& Thrift, N. (eds.), International encyclopedia of human geography, pp.200-201, Elsevier, Amsterdam, Holland. ISBN: 9780080449111.

Silverman, D. (2010) - Doing qualitative research. SAGE, London, Great Britain. ISBN: 978-848600331.

Smit, B.; Wandel, J. (2006)-Adaptation, adaptivecapacity and vulnerability. Global Environmental Change, 16(3):282292. DOI: 10.1016/j.gloenvcha.2006.03.008.

Strauss, A. (1987) - Qualitative Analysis for Social Scientists. Cambridge University Press, Cambridge, Great Britain. ISBN: 978-0521338066.

Strauss, A.; Corbin, J. (1990) - Basic of Qualitative Research: Grounded Theory Procedures and Techniques. SAGE, Newbury Park, U.S.A. ISBN: 978-0803932517.

Thanawood, C.; Yongchalermchai, C.; Densrisereekul, O. (2006) - Effects of the December 2004 Tsunami and Disaster Management in southern Thailand. Science of Tsunami Hazards, 24(3):206-217. http://tsunamisociety. org/243thana.pdf.

Thomalla, F.; Downing, T.; Spanger-Siegfried, E.; Han, G.; Rockström, J. (2006) - Reducing hazard vulnerability: towards a common approach between disaster risk reduction and climate adaptation. Disasters, 30(1):39-48. 
Available at http://www.clacc.net/Documents/report/ j.1467-9523.2006.00305.pdf

Tuan, Y.-F. (1976) - Humanistic geography. Annals of the Association of American Geographers, 66(1):266-276, Washington, DC, U.S.A..

Turner, B.L.; Kasperson, R.E.; Matson, P.A.; McCarthy, J.J.; Corell, R.W.; Christensen, L.; Eckley, N.; Kasperson, J.X.; Luers, A.; Martello, M.L.; Polsky, C.; Pulsipher, A.; Schiller, A. (2003) - A framework for vulnerability analysis in sustainability science. Proceedings of the National Academy of Sciences of the United States of America, 100(14):8074-8079. DOI: 10.1073/pnas. 1231335100.

UNISDR (2007) - Hyogo Framework for Action 2005-2015: Building the Resilience of Nations and Communities to Disasters. 25p., UNISDR - The United Nations Office for Disaster Risk Reduction Available at http://www.unisdr. org/files/1037_hyogoframeworkforactionenglish.pdf

Valentine, G. (2005) - Tell me about... using interviews as a research methodology. In: Flowerdew, R. \& Martin, D. (eds), Methods in Human Geography: A Guide for Students Doing a Research Project, pp.110-127, Pearson, Harlow, U.K. ISBN: 978-0582473218.

Webster, D.; McElwee, P. (2009) - Urban Adaptation to Climate Change: Bangkok and Ho Chi Minh City as Test Beds. In: Worldbank (eds.), Fifth urban research symposium, cities and climate change: Responding to an urgent agenda, 17p., Marseille, France. Available at http://siteresources. worldbank.org/INTURBANDEVELOPMENT/ Resources/336387-1256566800920/65052691268260567624/Webster.pdf.

Wehrhahn, R.; Bercht, A.L.; Krause, C. L.; Azzam, R.; Kluge, F.; Strohschön, R.; Wiethoff, K.; Baier, K. (2008) - Urban restructuring and social and water-related vulnerability in mega-cities - the example of the urban village of Xincún, Guangzhou(China). Die Erde, Zeitschrift der Gesellschaft für Erdkunde zu Berlin, 139(3):227-249.

Willroth, P.; Revilla Diez, J.; Arunotai, N. (2011) - Modelling the economic vulnerability of households in the PhangNga Province (Thailand) to natural disasters. Natural
Hazards, 58(2):753-769. DOI: 10.1007/s11069-0109635-1.

Willroth, P.; Massmann, F.; Wehrhahn, R.; Revilla Diez, J. (2012) - Socio-economic vulnerability of coastal communities in southern Thailand: the development of adaptation strategies. Natural Hazards and Earth System Sciences, 12:2647-2658. DOI: 10.5194/nhess-12-26472012.

Wisner, B. (2004) - Assessment of capability and vulnerability. In: Bankoff, G.; Frerks, G.; Hilhorst, D. (eds.), Mapping vulnerability: disasters, development and people, pp.183193, Earthscan, London. ISBN: 978-1853839641.

Wisner, B. (2006) - Self-assessment of coping capacity: Participatory, proactive, and qualitative engagement of communities in their own risk management. In: Birkmann, J. (eds.), Measuring vulnerability to natural hazards. Towards disaster resilient societies, pp.316-328, United Nations University, Tokyo, Japan. ISBN: 9789280811353.

Wisner, B.; Blaikie, P.; Cannon, T.; Davis, I. (2004) - At Risk: Natural Hazards, people's vulnerability and disasters. $2^{\text {nd }}$ edition. 471p., Routledge, New York. ISBN: 0415252164.

Wongpreedee,A.; Mahakanjana, C. (2011)-Decentralization and Local Governance in Thailand. In: Berman, E. M. (eds.), Public Administration in Southeast Asia, pp.53-78, CRC Press. ISBN: 978-1420064766.

World Bank (2009) - Climate Change Impact and Adaptation, StudyforBangkokMetropolitam Region. FinalReport. World Bank, Panya Consultants, Bangkok, Thailand. https:// openknowledge.worldbank.org/handle/10986/3115.

World Bank (2012) - Thai Flood 2011. Rapid Assessment for Resilient Recovery and Reconstruction Planning. World Bank, Bangkok, Thailand. https://www.gfdrr.org/sites/ gfdrr.org/files/publication/Thai_Flood_2011_2.pdf.

Zou, L.-L.; Wei, Y.-M. (2010) - Driving factors for social vulnerability to coastal hazards in Southeast Asia: results from the meta-analysis. Natural Hazards, 54(3):901-929. DOI: $10.1007 / s 11069-010-9513-x$. 